\title{
DEVELOPMENT OF INDEPENDENT BASIC TRAINING MODEL BASED ON EARLY CHILDHOOD TEACHER COMPETENCY IN KUBU RAYA REGENCY
}

\author{
Muhammad Yusuf ${ }^{1)}$, M.Syukri ${ }^{2)}$, Wahyudi $^{3)}$ \\ ${ }^{1)}$ Universitas Tanjungpura, Pontianak, Indonesia \\ E-mail: ucup.kkr@gmail.com \\ ${ }^{2)}$ Universitas Tanjungpura, Pontianak, Indonesia \\ E-mail: syukri_fkip@yahoo.com \\ ${ }^{3)}$ Universitas Tanjungpura, Pontianak, Indonesia \\ E-mail:wyudi_fkip@yahoo.com
}

\begin{abstract}
In carrying out its duties and functions, early childhood teachers must meet the qualifications and competencies required in accordance with PERMENDIKBUD no. 137 of 2014 on the National Standards of Early Childhood Education. But in fact of early childhood teachers have varying variations in qualification and competence. Still found educators who are elementary education, but so many educators who have secondary education (high school or vocational school) and very few who have diploma and graduate education, although not relevant / appropriate with the field of education of early childhood. It is necessary to design a basic level tiered training that can be used by the organizers that are effective and efficient to overcome these problems. The purpose of this study is to develop the basic training model based on the competence of early childhood teachers in Kubu Raya. This study includes a type of research development with reference to the opinion of Borg \& Gall. Products developed based on preliminary research are basic competency-based training and training. The test subject in this research is subject of expert, that is expert in the field of Early Childhood Education training, as well as subject of the basic training participants as potential users of the product. The determination of participant subjects for operational field test amounted to 19 teachers of Kubu Raya. Data collection techniques were conducted by questionnaire. The questionnaire is used to assess the training design that is developed in terms of needs analysis, the preparation of training programs, recruitment of participants, preparing training plans, trainers, training facilities, training schedules and administration. Data were analyzed descriptively, quantitatively and qualitatively. The results showed that, on field trial of basic education model based on the competence of early childhood teachers in Kubu Raya included in the effective category. The result of calculation of posttest result distribution shows the dominant calculation is effective as many as 10 people or $53 \%$. Thus, the basic training model based on the competence of the development result is feasible to be used by the basic training provider for teachers.
\end{abstract}

Keywords: Basic Training Model; Teacher Competency; Early Childhood

\section{INTRODUCTION}

The purpose of national education is the estuary of the educational process organized educational units at all levels. National education aims to develop the potential of learners to become human beings who are faithful and devoted to God
Almighty, have a noble character, healthy, knowledgeable, capable, creative, independent and become citizens of democratic and responsible (Law No. 20 of 2003, article 3 ). The success of educational units to achieve the objectives of education is determined by several factors such as curriculum, educators, learners, facilities and 
infrastructure, management, and school and community relations.

Educator as one of the determinants of the success of education, in carrying out its duties need to have a set of knowledge about how he should educate children. Educators are expected to facilitate the learning process so that the expected goals can be achieved optimally. The role of educators cannot be replaced by other objects, because educators are a central point in the effort to reform the learning and they become the key to the success of every effort to improve the quality of education.

Various reform efforts in the field of education have been and will continue to be done, but educators still hold a central role in the education process. The curriculum is enhanced, facilities and facilities are equipped, but if not matched with the ability of educators in implementing it, then everything will be less meaningful. Given the important role of educators in the education process, the government explicitly formulate four competencies that must be owned by educators including educators of Early Childhood Education (PAUD).

Early Childhood Education (PAUD) according to Yuliani (2013: 7) is the provision of efforts to stimulate, guide, nurture and provide learning activities that will produce skills and skills of children. While PAUD educators according to Yuliani (2013: 8) are professionals in charge of planning, implementing the learning process, and assess the learning outcomes, and conduct mentoring, care, care, and protection of students.

From the above opinion, the authors conclude that the role and task of PAUD educators is to plan, implement the learning process, and assess the learning outcomes, and conduct mentoring, care, care and protection of students through efforts to provide stimulation and learning that will result in the ability and skills of children.

In carrying out its duties and functions, PAUD educators must meet the qualifications and competencies required by Permendikbud no. 137 of 2014 on the National Standards of Early Childhood Education. In chapter VII, article 24 states that early childhood educators consist of PAUD teachers, companion teachers and young companion teachers. Each level of educator has different authority and responsibilities in performing their duties in accordance with their qualifications and competencies.

Based on the results of preliminary studies that the authors do in Kabupaten Kubu Raya, obtained data primarily on the path of non-formal education has variations that vary in qualification and competence. Still found educators who are elementary education (SMP), but so many educators who have secondary education (high school or vocational school) and very few who have diploma and graduate education, although not relevant/appropriate with the field of education of early childhood.

On the other hand, many PAUD educators who perform their duties exceed the authority that should be. From the data above we can see there are PAUD teachers who only graduated from junior high school has been playing a core teacher in PAUD institution. On the basis of these conditions, an effort is needed for all educators at the level of early childhood education with the authority in accordance with the competence and qualifications should be.

Based on these conditions, since 2011 the Directorate of Teacher Development and Education Personnel PAUD and DIKMAS (Dit PGTK PAUD and Dikmas) Directorate General Teachers and Education Personnel conduct various education for PAUD educators starting from central, provincial and district / city level which aims to improve the competence of educators in a continuous and tiered. The training includes basic training, advanced training and advanced training. Basic training is aimed at preparing educators as competent young teachers. Advanced training is aimed at preparing competent educators as companion teachers and proficient training aimed at preparing competent teachers as PAUD teachers.

The tiered training is carried out from the central, provincial to district/city levels organized by eligible institutions or designated as organizers. The success of this training is in addition to depending on the quality of the training organizers is also determined by the quality of trainers, companions, evaluators and implementation strategy of training and other related components.

However, in its implementation from 2011 to 2017 out of 938 teachers, who have been trained in Kabupaten Kubu Raya using APBN and APBD funds only 98 teachers. Many obstacles encountered in the implementation of basic training, among which the limited training of participants and the cost is large enough because it must be implemented for 5 days and use hotel facilities, so that budget and APBN budget to complete the entire teacher is not sufficient.

Meanwhile, tiered training starting from the basic level is needed to meet the competence of early childhood teachers. This training is expected to be implemented by the government in the regency / municipality but in the implementation the basic education program still has limited both fund and trainer / instructor. It is necessary to design a basic level tiered training that can be used by the organizers that are effective and efficient to overcome these problems. So that efforts attract the attention of the authors to prepare a research proposal on "Development of basic training model based on the competence of early childhood teachers in Kabupaten Kubu Raya". 


\section{Methodology}

This research uses research and development method or Research and Development (R \& D). According to Borg and Gall (1991: 772) "Educational research and development $(\mathrm{R} \& \mathrm{D})$ is a process used to develop and validate educational products" (R \& D is a process used to develop and validate educational products). According Sugiyono (2016: 333) research and development is a research method used to produce a particular product, and test the effectiveness of the product. So research development is a method to produce a particular product or refine the existing product and test the effectiveness of the product.

Research and development ( $\mathrm{R} \& \mathrm{D})$ methodology is used in this research for the purpose of product design training development starting from the exploration of case that happened at the implementation of basic level training to improve the competence of early childhood teachers in Kubu Raya Regency to develop theoretical training design. The results of the exploration of the problems undertaken in the needs analysis are then used as the foundation in preparing the training design product.

Tests conducted to collect data about the design of training that will be used as a model. For that test design is also a guide in terms of seeing the level of completeness of the training model. Some of the steps in this trial are illustrated below: The test subjects of this training design model will be established based on the need for the development of the training model. Two experts for models in Early Childhood Education (PAUD) and training. These experts are selected based on the qualifications of the competencies desired by the research objectives, then the results of the development and approval of the two research thesis supervisors. The model was also assessed by three instructors and participants who attended the training.

The data of this research are quantitative data and qualitative data. Quantitative data were obtained from the results of the model assessment questionnaire analyzed and consulted with experts. While qualitative data are responses, suggestions and input from experts, training instructors and participants.

Analysis of the test results of this model, then done by way of qualitative analysis, descriptive analysis and quantitative analysis. a) Qualitative analysis is done by commenting and reflecting technique on some information which is captured by descriptive statement in questionnaire, and observation. This qualitative analysis will be found, especially in the case of comments and opinions from two experts on the initial draft of the training model. b) Descriptive analysis is to measure the effectiveness of the model, then the data of the respondents will be calculated from the percentage.
All product packages from the development of parts of this model are assessed with a range of values 1-4 and are also given comment fields. Interpretation of range 1-4. c) Quantitative analysis is to measure the effectiveness of basic education before and after using the basic training model based on the competence of early childhood teachers. In this research, quantitative analysis is calculated by using dependent sample t-test or often termed by paired sample t-test is a type of statistical test that aims to compare the average of two groups paired together. The test formula used is:

$$
t=\frac{\overline{\mathrm{x}}_{1-\bar{x}_{2}}}{\sqrt{\frac{\mathrm{s}_{1}{ }^{2}}{n_{1}}+\frac{\mathrm{s}_{2}{ }^{2}}{n_{2}}-2 r\left(\frac{s_{1}}{\sqrt{n_{1}}}\right)\left(\frac{s_{2}}{\sqrt{n_{2}}}\right)}} \ldots \ldots \ldots \ldots \ldots \ldots \ldots
$$

Meanwhile, to determine the effectiveness of the training, the researcher made the criteria of the effectiveness of the training into four categories: Very Effective, Effective, Less Effective, Very Less Effective. The formula used in determining the criteria according to Sudjana (2005:) is as follows:

$p=\frac{\text { Higest Score-Lowest Score }}{\text { Total of Standarized Category }}$

\section{RESULTS AND DISCUSSIONS}

\section{A. Research Results}

In the competency analysis phase, the researcher identifies the basic curriculum structure of the training needed in the development of a competency-based basic training model. In this study, the researcher develops curriculum structure and training strategy, with the aim that participants are not bored in the learning process.

The result of the preliminary interview with the Head of Himpaudi Kabupaten Kubu Raya is known that there are still many PAUD educators who have not fully possessed the teaching skills and the educational qualifications are not from PAUD. For that one effort to improve the professionalism of PAUD educators is by holding activities Diklat Tiered.

Observations on basic training activities, researchers can conclude some characteristics of participants in the training, among others: a) the costs incurred to follow the training is very expensive because to mebiayai participant consumption, rental of the building, so the institution only awaits the implementation of training organized by the Office of Education and Culture; b) At the time of attending the basic training the participants have to leave the class for 5 days because they have to follow the basic training; c) Participants are less enthusiastic in the training activities, seen from the activities of learners 
during the process of training activities that only "sit sweet" and "hear"; d) The involvement of trainees in the learning process is still very low, so trainees tend to be passive and easily saturated; and e) The learning method used is still dominated by the lecture method, so the understanding of the concept and the achievement of the learning achievement of the participants is still low because of the limited teaching materials provided only in the form of print out of the power point only.

The retrieval of trial result data on basic competency-based training model is done by expert and user of training model. The retrieval of user experimental data is performed after the basic training model gets the expert judgment. The training expert who acts as a validator is Dr. M. Syukri, M.Pd who is an academic who often fills in training in the field of Out-School Education (PLS) in West Kalimantan as well as mentors 1 . The second training expert who acts as a validator is Dr. Wahyudi, who is also an academic who has filled many activities in PAUD training in West Kalimantan as well as mentor 2.

Expert training conducted by Dr. M. Syukri, M.Pd on April 11, 2018 as a training expert 1 and conducted by Dr. Wahyudi on 2 February 2018 as training expert 2 . The result of percentage calculation from material experts, based on 39 indicators of effectiveness of basic competency-based training in early childhood teachers in Kabupaten Kubu Raya obtained $96.6 \%$ results with the classification of basic training model valid and quite feasible to use .

User trials are performed after obtaining valid results against trials that have been conducted by both training specialists. This user trial was conducted on February 3 to March 3, 2018. User trials were conducted by a total of 19 PAUD teachers from Kabupaten Kubu Raya. The result of calculation of percentage of users, based on 39 indicators of the effectiveness of basic training based on competence in early childhood teachers in Kabupaten Kubu Raya obtained $85.19 \%$ with the classification of basic training model is feasible to use.

Data of pretest and posttest result from trial to user, analyzed using quantitative analysis calculated by using dependent sample t-test or often termed by paired sample t-test that is type of statistic test which aim to compare mean of two paired group. The calculation results using SPSS are:

Based on the calculation of statistics using SPSS note that the value of Sig. (2.tailed) of 0.000 $<0.05$, the researcher can conclude that there is a significant difference between the learning outcomes of the basic training participants before and after using the basic competence-based training model.

While the frequency distribution of posttest results to measure the effectiveness of the training implementation by using the basic competence-based training model can be seen in the following table:
Table 1: Paired Samples Test

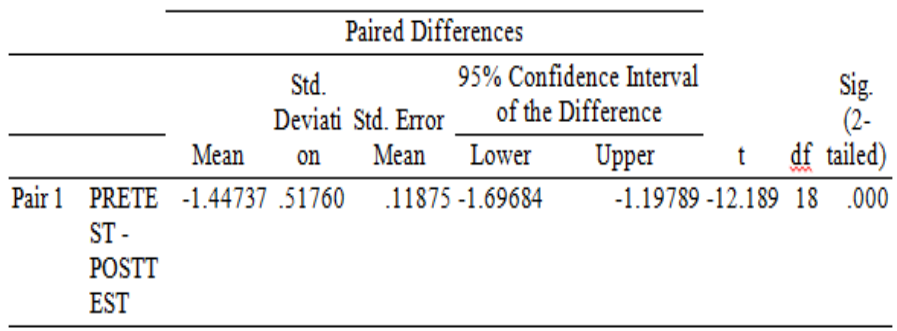

Table 2: Distribution of Postest Result

\begin{tabular}{cccc}
\hline Postest Score & Categoy & Frequency & Presentage \\
\hline $5.75-6.18$ & Very Less Effective & 2 & 10 \\
\hline $6.19-6.62$ & Less Effective & 1 & 5 \\
\hline $6.63-7.06$ & Effective & 10 & 53 \\
\hline $7.07-7.50$ & Very Efektif & 6 & 32 \\
\hline & Total & 19 & 100
\end{tabular}

\section{B. Discussions}

Alternatives that can be taken to overcome these weaknesses, including through competencybased education and training for PAUD educators are developed and recommended. Preparation of education and training model is an effort to improve the competence of PAUD educators in carrying out their main tasks and functions so as to improve its performance. The effort is an innovation in improving the quality of education and training. With the increasing competence of PAUD educators in carrying out their main tasks and functions, learning is expected to be effective and efficient and the quality or quality of graduates also increases.

Based on the above description, the competency-based education and training model for PAUD educators is one of the efforts to develop the quality of competence, because based on the study of Government Regulation (PP) No. 101 of 2000 article 2 explains that the training objectives are:

1. Increase knowledge, expertise, skill and attitude to be able to carry out professional job duties based on the personality and ethics of civil servants in accordance with the needs of agencies; 
2. Creating employees who are able to play a role as a renewal and adhesive of the unity and unity of the nation;

3. Establish the attitude and spirit of serviceoriented devotion, shelter, and community empowerment;

This is in accordance with the opinion of Leslie Kelly (1994: 2) mentions training is for the good of plant production it is a way to solve production problems through people, it is specific and helps people to acquire skill through the use of what they learn means training is a way to solve production problems through people, it is specific and helps people to acquire skills through the use of what they learn.

Based on the presentation of the results and the above opinion it can be concluded that the implementation of education and training programs is very important for educators and education personnel PAUD good for the present or future, because with the education and training skills, knowledge, skills, attitudes and productivity of educators and PAUD educational personnel will increase, the result is the learning process in PAUD institutions in accordance with which expect government, parents and users of education.

The basic competence-based training model that researchers develop in its implementation is divided into 3 stages in accordance with the Regulation of the Minister of Manpower and Transmigration of the Republic of Indonesia Number 8 of 2014 on guidelines for the implementation of competency-based training mentioned Competency Based Training (PBK) is a Training that must be done comprehensively from planning to evaluation, so that increased knowledge, skills and work attitude can be done. The training orientation is emphasized on improving the ability or competence to perform specific work according to the demands of the job market or community development needs. The 3 stages are:

\section{1) Stage of preparation}

Preparation stage starts from the preparation of basic design based on competency based on the experience of empiric researchers as the basic training organizers and refers to basic training guidelines issued by Directorate of education and educational personnel training for early childhood education and community education. After the design is completed and then validated by 2 experts namely Dr. M.Syukri, M.Pd and Dr. Ir. Wahyudi and made improvements to basic training design.

The design will be completed by trial in coordination with the Chairman of HIMPAUDI Kabupaten Kubu Raya to select the basic training participants in accordance with the guidelines must meet the requirements:
a. Physically and mentally healthy
b. Willing to follow the training from beginning to end
c. Preferably have attended PAUD training
d. Preferably PAUD educators who have served at least 1 year.
e. Minimum age of 17 years
f. Minimum education qualifications or equivalent
g. Never had a similar activity

From the registration result, 20 participants of the basic competency-based training program came from PAUD teachers in Kabupaten Kubu Raya, and the researchers prepared equipment and training materials in the form of ATK and module.

\section{2) Implementation Phase}

In the implementation phase begins with the opening and technical explanation of the implementation of basic training base on competence by the researchers followed by the pretest where the participants work on the problem of objective as much as 40 questions on the sheet of answers that have been provided.

The strategies and methods used in this basic competency-based training are face-to-face as much as 48 hours of lesson and self-directed tasks of 240 hours of lesson, which are done by referring to the modules that have been prepared by the completion of the face-to-face material stage.

\section{3) Evaluation and Assessment Stage}

After the whole series of face-to-face and selfdirected tasks have been completed by the participants as evidenced by the independent duty report, an evaluation is conducted with 40 posttest executions of objective options and an assessment of the self-employment report. If participants are graduated face-to-face and self-directed, participants will be registered on the Education Directorate of Education Directorate of GTK PAUD and Dikmas using the User and Password owned by HIMPAUDI West Kalimantan Province and a certificate indicating that participants have completed all stages of basic education and graduated.

The basic competence-based training model that researchers develop in this study are:

\section{Curriculum}

The curriculum used in the basic training is faceto-face for 48 hours of lesson, after the participants complete all the face-to-face material, then followed by the implementation of independent tasks conducted by the training participants in each institution as much as 210 hours of lessons or for 30 working days.

In the implementation of independent duties undertaken not in the guidance of the companion and 
the participants are not equipped with modules as material to perform independent tasks, so that the implementation of the task independently the impression is only the tasks that participants do as a condition of graduation just no meaning. This is evidenced from the results of independent tasks mostly only in the form of copy paste from the previous participants.

While the curriculum in the basic competencebased training model was developed by combining the two basic training strategies namely face-to-face and independent tasks by using the module in accordance with the stages of basic training materials.

The training participants receive face-to-face material in module 1 followed by self-directed tasks performed in their respective institutions and the results of their mandated tasks are checked by a companion. If the self-assessment report of stage 1 is stated correctly, then the trainee can proceed to tap 2 or module 2 with the same stages, until all modules are completed by the participants. At the end of the stage the participants only compile the self-directed report entirely and the participants can follow the posttest and the independent task can be assessed as a whole by the companion.

\section{Teaching materials (modules)}

Teaching materials provided by the organizer of activities in the implementation of the previous training is a collection of powerpoint material created by resource persons who adapted to the material that has been received by speakers at the time of PCP.

While the teaching materials in the basic training model based on this competence, the researcher developed from the material received by the resource persons when following the PCP. The collection of materials that researchers combine into modules that are divided into five modules and packaged very simple equipped with examples of action to be easily understood by the trainees.

\section{Training schedule}

The training schedule which was arranged by the organizer of the activity in the previous training was the face-to-face 48 hours of pursuit that was held for five days from 7.30 to 17.15 and the participants did not stay, if the participants provided the lodging then held for four days from 7.30 to 21.30. after face to face followed by independent duties during 210 school hours or 30 working days in each training.

While the schedule in the basic training model based on this competence, the researcher develops with the agreement to the agreement between the organizers, the speakers and the participants by adjusting the schedule of readiness of the participants and the steps taken are face-to-face and independent tasks in modules 1 through 5 .
Analysis of posttest evaluation result of competencybased training for PAUD educator proves that there is a significant difference from the application of developed training model, and the result of calculation of posttest result distribution shows the dominant calculation is effective as many as 10 people or $53 \%$.

\section{CONCLUSION AND SUGGESTION}

\section{A. Conclusion}

From the result of the research and the above explanation, the researcher concludes that this basic competency-based training model is effective in improving the competence of teachers and educators PAUD, this is because the basic competency-based training model is based on the results where PAUD educators are not only presented materials but PAUD educators given materials and practice and after face to face done independent tasks that are done independently by making RPPM, RPPH and doing learning process in each institution.

After the independent duties are completed, the companion performs an assessment of the independent duty report of each participant and if passed the face-to-face and independent tasks, the participant will be awarded the certificate by the training provider and known by the Director of Teacher Development and Teaching Staff of Early Childhood Education and Community Education Jakarta.

\section{B. Suggestion}

Based on the results of this study, the researchers provide advice should the organizers training or providers who are given the authority to organize basic training in scheduling PAUD teacher training is really taken into account the right time for example at the time of institution or other holidays. Training activities conducted at times when the participants did not teach so it can be possible all teachers can follow the training and learners are not harmed.

For training providers or providers who are given the authority to organize basic training, they should cooperate with other parties or agencies in order to sponsor basic training programs in order to help ease the financing of training participants sourced from self-fund.

\section{REFERENCES}

Kementerian Pendidikan Dan Kebudayaan Direktorat Jenderal Guru Dan Tenaga Kependidikan Direktorat Pembinaan Guru Dan Tenaga Kependidikan Paud Dan Dikmas. 2015. Pedoman Diklat Berjenjang

Kelly, Leslie (1994) The ASTD Technical And Skills Training Handbook. United States Of America Peraturan Menteri Tenaga Kerja dan Transmigrasi Republik Indonesia Nomor 8 Tahun 2014 
Tentang Pedoman Penyelenggaraan Pelatihan Berbasis Kompetensi

Peraturan Menteri Pendidikan dan Kebudayaan Republik Indonesia Nomor 137 Tahun 2014 Tentang Standar Nasional Pendidikan Anak Usia Dini

Peraturan Pemerintah Republik Indonesia Nomor 101 Tahun 2000 Tentang Pendidikan dan Pelatihan Jabatan Pegawai Negeri Sipil

Sujiono, Yulia Nuraini (2013). Konsep Dasar Pendidikan Anak Usia Dini. Jakarta: Indeks.

Sugiyono (2016). Metode Penelitian Administrasi. Bandung: Alfabeta

Undang-Undang Republik Indonesia Nomor 20 Tahun 2003 Tentang Sistem Pendidikan Nasional

Walter R. Borg \& Meredith D. Gall, (1991). Eucational Research An Introduction, longman Inc. 